\title{
PENYULUHAN HUKUM PENTINGNYA KEPEMILIKAN SERTIFIKAT TANAH TENTANG PENDAFTARAN TANAH DI DESA KEDUNGBOTO KEC. LIMBANGAN KAB. KENDAL
}

\author{
A. Saiful Aziz \\ Dosen Fakultas Agama Islam, Universitas Wahid Hasyim Semarang
}

\begin{abstract}
The certificate is a proof of rights which is valid as a proof of strong ownership of physical data and juridical data contained in the measuring certificate and land book of the relevant rights in accordance with Article 19 Paragraph (2) of the LoGA. In practice in the community it turns out that the certificate of land rights is not the only proof of ownership of land rights, but old rights such as girik and receipts are proof of ownership of land rights, which are based on Article 24 paragraph (1) PP 24 of 1997 Problems to be resolved in this study (1) how the legal power of land rights certificates (2) what efforts can be made to ensure legal certainty in the land sector.
\end{abstract}

Keyword: Certificate, ownership, legal power

\section{PENDAHULUAN}

Adanya kemajuan ekonomi, maka makin bertambah banyak tanah rakyat yang tersangkut dalam kegiatan ekonomi seperti : tanah dijadikan obyek dalam jual beli hak atas tanah, juga tanah sebagai jaminan utang. Karena itu makin terasa perlunya jaminan kepastian hukum dan kepastian hak dalam bidang pertanahan. Untuk memenuhi kebutuhan tersebut maka pasal 19 UUPA memerintahkan kepada pemerintah untuk mengadakan pendaftaran tanah di seluruh wilayah
Republik Indonesia. Dari kegiatan pendaftaran tersebut maka akan mendapatkan sertifikat hak atas tanah sebagai alat pembuktian yang kuat pasal 19 ayat (2) huruf c UUPA. Dalam hukum tanah dikenal 2 (dua) macam sertifikat yaitu sertifikat hak atas tanah dan sertifikat hak tanggungan. Sertifikat hak atas tanah merupakan tanda bukti hak atas tanah dan sertifikat hak tanggungan adalah tanda bukti adanya hak tanggungan.. Sertifikat menurut PP 24/1997 adalah surat tanda bukti hak sebagaimana dimaksud dalam pasal 19 ayat (2) huruf c UUPA untuk hak atas tanah, hak pengelolaan, tanah wakaf, hak milik atas satuan rumah susun dan hak tanggungan 
yang masing-masing sudah dibukukan dalam buku tanah yang bersangkutan. Dalam undang-undang No. 5 tahun 1960 yang lazimnya disebut dengan UUPA dikenal hak-hak atas tanah seperti Hak Milik, Hak Guna Usaha, Hak Guna Bangunan, Hak Pakai dan Hak Pengelolaan. Semua hak atas tanah itu memberikan kewenangan kepada orang yang mempunyainya, hanya bedanya terletak pada luasnya kewenangan dalam menggunakannya, yakni untuk keperluan apa dan berapa lama tanah tersebut dapat digunakan. Hak Milik menurut pasal 20 UUPA adalah hak turun temurun terkuat dan terpenuh yang dapat dipunyai orang atas tanah, dengan mengingat ketentuan dalam pasal 6 UUPA.. Hak Guna Usaha menurut pasal 28 UUPA, adalah hak untuk mengusahakan tanah yang dikuasai oleh Negara, dalam jangka waktu sebagaimana tersebut dalam pasal 29 guna perusahaan pertanian, perikanan atau peternakan. Hak Guna Usaha diberikan atas tanah yang luasnya paling sedikit 5 Ha, dengan ketentuan bahwa jika luasnya $25 \mathrm{Ha}$ atau lebih harus memakai investasi modal yang layak dan teknik perusahaan yang baik, sesuai. Sebagai target dari kegiatan pembinaan ini adalah warga masyarakat khususnya warga masyarakat Desa
Kedungboto Kec. Limbangan Kab. Kendal ini mengetahui dan memahami pentingnya kepemilikan sertifikat sebagai bukti kepemilikan hak atas tanah, dan memberikan upaya penyadaran huku menhgenai pentingnya kepemilikan sertifikat sebagai bukti penguasaan hak atas tanah sekaigus dalam upaya untuk membentuk ketertiban dalam masyarakat dan untuk dapat memberikan jaminan kepastian hukum dan perlindungan hukum kepada masyarakat.

\section{METODE}

Dalam kegiatan penyuluhan hukum Pengabdian pada masyarakat ini, metode yang digunakan adalah pendidikan dan penyadaran di bidang hukum. Pendidikan ini dimaksudkan untuk memberikan pemahaman kepada para warga masyarakat bahwa sedemikian pentingnya dimilikinya suatu surat sebagai bukti kepemilikan ataupun sebagai bukti penguasaan hak atas tanah yang dilakukan dengan melalui upaya pendaftaran tanah. Dengan adanya kegiatan pengabdian masyarakat yang dilakukan ini, memunculkan kesadaran masyarakat untuk melakukan pendaftaran tanah, meski pendaftaran tanah bukan merupakan syarat sahnya terjadinya jual beli. Selain itu kegiatan pengabdian ini dilakukan dengan 
bentuk kegiatan berupa penyuluhan dan dialog interaktif. Model ini digunakan agar masyarakat tidak merasa digurui sehingga hasilnya diharapkan efektif. Sebagai khalayak sasaran dalam kegiatan pengabdian ini adalah warga desa Desa Kedungboto Kec. Limbangan Kab. Kendal Dipilihnya warga masyarakat yang berlokasi di daerah kedungboto adalah dengan pertimbangan bahwa warga masyarakat di daerah itu oerlu mendapatkan informasi dan sosialisasi mengenai pentingnya kepemilikan sertifikat sebagai bukti penguasaan hak atas tanah melalui pendaftaran tanah. Hal ini didasari juga oleh suatu pemikiran bahwa daerah Bandungan merupakan daerah yang mempunyai potensi ertanian yang cukup tinggi di Kabupaten Kendal , sehingga semakin besar kemungkinan banyak terjadi praktik jual beli tanah, yang kelak akan dipergunakan sebagai sarana pertanian. Dengan dasar tersebut, maka tim pengabdian memandang perlu untuk melakukan sosialisasi mengenai pentingnya kepemilikan sertifikat sebagai bukti penguasaan hak atas tanah. Kegiatan pengabdian ini juga berusaha untuk menghindarkan terjadinya penguasaan hak atas tanah yang dilakukan oleh pihak yang tidak berhak atas tanah yang dikuasainya, oleh karena itu penting adanya bukti kepemlikan atas tanah yang berupa sertifikat. Sasaran strategisnya dalah pengurus RT/RW di wilayah Desa Kedungboto Kec. Limbangan Kab. Kendal. Dengan harapan agar para warga dapat menyebarluaskan informasi dan hasil sosialisasi tersebut pada lingkungan masingmasing.

\section{HASIL DAN PEMBAHASAN}

Hasil kegiatan pengabdian kepada masyarakat ini merupakan salah satu uaya untuk memberikan pengetahuan, informasi, pemahaman, dan penyadaran kepada masyarakat mengenai pentingnya kepemilikan sertifikat tanah sebagai bukti penguasaan hak atas tanah. Dari kegiatan yang telah dilakukan oleh Tim pengabdian, dapat kami laporkan sebagai berikut. Dalam melakukan pengabdian masuyarakat mengenai sosialisasi pentingnya kepemilikan sertifikat tanah tanah sebagai bukti penguasaan hak atas tanah yang dilakukan di desa Jetis kecamatan Bandungan Kabupaten Semarang ini tidak mengalami hambatan yang berarti. Kegiatan pengabdian ini bertempat di Masyarakat Desa Kedungboto Kec. Limbangan Kab. Kendal dalam bentuk Pelaksanaan penyuluhan hukum. Hasil dari kegiatan pengabdian ini adalah sebagai berikut: 1 . 
Peserta pengabdian merasa antusias terhadap materi yang diberikan oleh penyaji. 2 . Terjadi interaksi timbal balik antara peserta dengan penyaji materi. 3. Terjadi diskusi mengenai materi yang disajikan. 4. Adanya pemahaman, dan kesadaran dari para peserta mengenai pentingnya kepemilikan sertifiikat sebagai butki penguasaan hak atas tanah, sehingga menimbulkan adanya adanya kesadaran untuk melakukan upaya pendaftaran tanah.

\section{SIMPULAN DAN SARAN}

$$
\text { Berdasarkan hasil evaluasi, }
$$
pengamatan dan tanggapan langsung dari peserta pelatihan, kegiatan pengabdian ini cukup berhasil mengingat adanya peningkatan pemahaman mengenai pentingnya kepemilikan sertifikat tanah sebagai bukti penguasaan hak atas tanah Partisipasi dan responsi peserta juga sangat baik, terlihat dari banyaknya tanggapan dan pertanyaan yang diajukan, termasuk dilihat dari jumlah banyaknya jumlah peserta, keaktifan, dan diskusi. Mengacu pada target dan luaran serta tujuan kegiatan penyuluhan hukum ini maka dengan dilaksanakannya kegiatan penyuluhan hukum ini maka masyarakat telah memahami amanat undang-undang yang mengharuskan kepala desa menjadi hakim desa, yang awalnya tidak paham menjadi paham. Dengan metode ceramah, tanya jawab, serta pemberian contoh, maka diharapkan tujuan dari kegiatan ini tercapai. Adapun hasil yang dicapai dari pelaksanaan kegiatan ini, adalah

\section{A. Hasil Penyuluhan}

1. Masyarakat Desa Kedungboto Kec. Limbangan Kab. Kendal dalam pemahaman hukum tentang masalah keperdataan sudah meningkat. Dengan pertanyaan-pertanyaan masyarakat saat penyuluhan hukum tersebut dapat disimpulkan bahwa masyarakat sudah pemahami prosedur penyelesaian sengketa keperdataan yang terjadi pada masyarakat dan khususnya bagi penanya .

2. Penyuluhan hukum ini bukan saja dalam bidang penyuluhan hukum saja akan tetapi kegiatan lain yang dilakukan adalah tata cara penyusunan Peraturan Desa.

3. Kekuatan hukum sertifikat hak atas tanah merupakan jaminan kepastian hukum dari sertifikat sebagai alat bukti kepemilikan yang bersifat kuat artinya sepanjang tidak dibuktikan sebaliknya oleh pihak lain yang merasa berhak dan mempunyai alat bukti untuk membuktikannya maka 
dalam hal ini sertifikat tersebut mempunyai kepastian hukum bersifat materil (publikasi negatif berunsur positif) yang dianut dalam hukum tanah nasional, tetapi disisi lain juga sertifikat mempunyai kepastian hukum yang bersifat formil (publikasi postif) yaitu kepastian hukum dari sertifikat yang berisi ketentuan tertulis yang tertera dalam Undang-Undang atau peraturan lainnya adalah bersifat mutlak artinya tidak bisa diganggu gugat. Beberapa hal yang dapat melemahkan kekuatan hukum sertifikat hak atas tanah jika dilihat dari kepastian dan kekuatan hukum bersifat formil (publikasi positif) yaitu pemakaian sistem publikasi negatif, lemahnya implementasi Pasal 32 ayat (2) PP. 24 Tahun 1997 dan tumpang tindihnya antara Undang-Undang pertanahan dengan asas hukum di pengadilan. Tetapi perlu juga diketahui bahwa sertfikat hak atas tanah bukan merupakan satu-satunya bukti kepemilikan hak atas tanah, karena untuk mengetahui pemilik tanah sebenarnya bukan hanya sertifikat yang dapat dijadikan baik bukti kepemilikan maupun sebagai alat bukti di pengadilan tetapi alat bukti lain pun bisa dijadikan sebagai bukti kepemilikan hak atas tanah termasuk Girik dan kwitansi tanah yang kadar kebenarannya dibuktikan di pengadilan.

4. Upaya yang harus dilakukan untuk mejamin kepastian hukum dalam bidang pertanahan dilakukan Pemerintah dalam hal ini Kementerian Negara Agraria dan Tata Ruang dalam menerbitkan sertifikat hak atas tanah harus berdasarkan asas kepastian hukum, asas kecermatan, dan asas aman untuk terjaminya kekuatan hukum dan kepastian hukum dari sertifikat yang diterbitkan. Dan juga melalui masyarakat berdasarkan asas keterbukaan Diharuskan kepada masyarakat pun yang mempunyai tanah harus memelihara baik data yuridis berupa jika ada peralihan hak, pembebanan hak ataupun yang lainnya harus segera di daftarkan ke Pemerintah (kementerian negara agraria dan tata ruang) dan jika menyangkut data fisiknya maka diharuskan mengetahui dimana lokasi tanah yang dipunyai, 
mengetahui batas-batas tanah tersebut. Artinya diharuskan adanya sinergi yang dilakukan antara pemerintah dan masyarakat untuk menjamin dan menjaga kepastian dan kekuatan hukum sertifikat hak atas tanah.

\section{Saran}

Dari temuan - temuan yang ada di lapangan, maka perlu kiranya direkomendasikan saran bahwa kegiatan ini dapat dilaksanakan secara terus menerus, agar informasi, pemahaman, dan pengetahuan masyarakat terhadap pentingnya kepemilikan sertifikat sebagai bukti penguasaan hak atas tanah semakin bertambah.

\section{DAFTAR PUSTAKA}

Effendi Bachtiar, 1993, Kumpulan Tulisan Tentang Hukum Tanah : Bandung, Alumni Bandung

Harsono, Boedi. 2002. Hukum Agraria Indonesia (Himpunan PeraturanPeraturan Hukum Tanah), (Cetakan Kelimabelas, Edisi Revisi. Djambatan: Jakarta.

Rahardjo, Sajipto 1980, Hukum, Masyarakat Dan Pembangunan, Cetakan Kedua, Alumni Bandung.

Santoso Urip, 2012. Hukum Agraria. Kencana Prenada Group: Jakarta. Syahrani, Riduan. 1999. Rangkuman Intisari Ilmu Hukum. Citra Aditya : Bandung.

Sitorus Oloan, 2004. Kapita Selekta Perbandingan Hukum Tanah, Mitra Kebijakan Tanah

Indonesia, Yogyakarta.

Soekanto Soerjono, 1994, Sosiologi Hukum, Raja Grafindo Persada Jakarta Sumardjono Maria S.W, 2007, kebijakan Pertanahan Antara Regulasi dan Implementasi, Penerbit Buku Kompas, Jakarta.

Supriadi, 2009, Hukum Agraria : Jakarta, Sinar Grafika 